\title{
An Empirical Study of ESP Learners' Experiences Using Edmodo in a Virtual Community of Practice
}

\author{
Jayanthi Muniandy \\ School of Languages, Literacies and Translations \\ Universiti Sains Malaysia, Pulau Pinang, Malaysia \\ Munir Shuib \\ National Higher Education Research Institute \\ Universiti Sains Malaysia, Pulau Pinang, Malaysia
}

\begin{abstract}
This study was conducted to investigate English for Specific Purposes (ESP) learners' experiences in using social learning network sites, namely Edmodo in a virtual community of practice environment. This study was also aimed to identify the challenges that the learners encountered in using Edmodo. Mixed-method research was employed to collect the data for this study; a questionnaire survey and a focus group discussion. The collected data was analysed through statistical and thematic analysis. The results showed that most of the ESP learners were of the opinion that Edmodo was effective as a platform for a virtual community of practice, particularly in terms of interaction and knowledge sharing. The findings also revealed that some learners have had difficulties in creating a social identity in the community because of the lack of collaboration among the team members. Therefore, it is suggested that genuine, consistent, and synergistic motivation from educators followed by the active involvement of learners will surely boost the engagement of peripheral participants in the community. This study is significant as it offers some insights into how ESP practitioners and learners use social learning networks in building an effective ESP virtual learning community to achieve the learning outcome of the ESP course.

\footnotetext{
KEYWORDS: Edmodo, English for Specific Purposes, Business English, social learning network, virtual community of practice
} 


\section{INTRODUCTION}

The use of social media has brought people a distance closer, especially when continuous discussion and sharing of information and interest embark on the network. According to Fisher et al., (2014), this process is basically known as a virtual community of practice (VCoP) in which people acquire knowledge from one another and simultaneously builds one's expertise. Wenger et al., (2002) state, a community of practice refers to a group of people who share similar interests and passion, communicate their knowledge, expertise, and experiences on certain issues or subjects.

Although social media is well known for continuous interaction, not all social media tools have the capacity to develop VCoP (Fisher et al., 2014). Besides, the use of social media especially Facebook and Twitter is not preferred by many higher education institutions as its invention was not meant for educational purposes (Yunkul \& Cankaya, 2017). Therefore, a platform that integrates the strength of both social network sites and learning management systems is developed to provide an interactive, flexible, and conducive learning environment (Yunkul \& Cankaya, 2017). One of the common social learning sites that have been used quite extensively in tertiary education is Edmodo (Ngo \& Ngadiman, 2019).

\section{PROBLEM STATEMENT}

Literature suggests that one of the major issues on the integration of technology in the ESP classroom is embedding traditional methods in online learning. For example, many language educators from tertiary institutions employ online learning platforms to upload announcements or content materials and assign quizzes or assignments (Warawudhi, 2017) rather than creating and developing online interaction and collaboration (Yunkul \& Cankaya, 2017). According to Ekici (2017), frequent online interaction is necessary to enhance learners' knowledge both in subject matter and skills. Other scholars have also identified that regular virtual interaction and collaboration gradually boost learners' confidence, skills, and social relationships (Akcaoglu \& Lee, 2016; Penfold, 2010; Zainal Abidin et al., 2018).

However, studies involving Edmodo in a VCoP environment are still very limited. Therefore, the present study aims to investigate ESP learners' experiences of using Edmodo as a platform for a VCoP and to identify possible challenges that ESP learners face in using Edmodo. This study attempted to answer the following research questions:

1. What are the perceptions of Business English learners' regarding their experiences in using Edmodo as a platform for a virtual community of practice?

2. What are the challenges faced by the Business English learners in using Edmodo as a platform for a virtual community of practice?

\section{LITERATURE REVIEW}

English for Specific Purposes, Communities of Practice, and Edmodo

The main objective of an ESP course is to equip learners with an adequate content-related matter of a specific field and language skills in order to perform well in an authentic situation (DudleyEvans \& St. John, 1998; Javid, 2015). Smoak (2003) elaborates the necessity of mastering ESP skills as they are known as fundamental skills that one needs to apply at the workplace. Thus, ESP learners are prepared with professional skills, which they could employ effectively in their job upon their graduation (Silva et al., 2013). The advent of educational technologies has allowed learners to develop their professional skills in a more effective and convenient way (Fisher et al., 
2014; Tyagi, 2012). According to Fisher et al. (2014), participation in an educational online tool would develop one's skills, expertise, and knowledge. Soto and Waigandt (2017) state ESP, which is taught through the community of practice increases the authenticity of the learning outcome. Community of practice that was developed based on situated learning theory and constructivism allows the sharing of real-life experiences, passion, and knowledge, and this approach eventually enables learners to perform well in an authentic situation (Fisher et al., 2014).

Since the underlying concepts of an ESP course are to prepare learners with sufficient knowledge and language skills based on a specific profession (Andrienko, 2017), the community of practice is perceived as the appropriate approach to be used in the teaching and learning of an ESP course because it emphasises student-centered learning that could increase one's expertise and skills through continuous interaction between learners, content, and educators (Soto \& Waigandt, 2017).

Wenger et al. (2002) indicate that an effective community of practice consists of the domain (e.g. topic of discussion that kindles interest and passion from others), community (e.g. a group of people who has similar interest and passion to join the community), and practice (e.g. regular participation in activities and sharing of ideas in the community). According to Penfold (2010), a community of practice has become an efficient approach in drawing learners in the community closer. It allows room for knowledge acquisition and contribution and social identity. Fisher et al. (2014) explain that regular communication in the community through technology or physical classroom would develop learners' skills, knowledge, confidence, and social relationship. This goes in line with Akcaoglu and Lee's (2016) notion that regular online social interaction increases learners' sense of belonging to the community as they could share their viewpoints, and author a particular content without hesitation. They further explain that this is achievable in a small group discussion as the learners feel comfortable sharing their views or even debating their points with fewer people in the group (Akcaoglu \& Lee, 2016).

Many researchers have indicated that educators-learners and learners-learners social connection through an online learning platform fulfil the real idea of communities of practice (Akcaoglu \& Lee, 2016; Fisher et al., 2014). In due course, the passive or shy learners in the community would gradually learn to contribute knowledge and be able to defend their opinion in the platform (Fisher et al., 2014). According to Wenger et al. (2002), a community of practice consists of three types of participants: core participants, active participants, and peripheral participants. Fisher et al. (2014) state that core participants are usually comprised of educators who assist and monitor the community while learners who actively engage in the community are known as active participants. Participants who observe the discussion in the community are known as peripheral participants. Fisher et al. (2014) elaborate that a community of practice would develop when more peripheral participants take part in the discussion and turn into active participants.

Many scholars have indicated that the features in the Edmodo are known as good assets for collaboration, interaction, participation, and sharing of knowledge (Alzain, 2019; Thongmak, 2013; Zainal Abidin et al., 2018). In one of the studies, Zainal Abidin et al. (2018) investigated 44 students on the effectiveness of Edmodo as an online group discussion and the team has found that most of the respondents show a positive attitude towards the platform as they could communicate and collaborate well with other learners through Edmodo. Zainal Abidin et al. (2018) reiterate that online collaboration with team members has become even more convenient through the Edmodo small-group feature. Besides, the team also discovered that discussions in a small group eventually 
builds the learners' proficiency in the English language, motivation, and confidence skills. In another study, Thongmak (2013) who investigates the adoption of Edmodo as a collaborative tool in the Management Information System course found that nearly $40 \%$ of the respondents use the platform to comment, alert, and share files. Thongmak (2013) explains further that since Edmodo offers a lot of benefits in the education field, educators are urged to educate learners to explore more on the features in the Edmodo to create an effective collaborative learning environment.

Ekici (2017) states that a community of practice is possible to be developed through Edmodo as its features have the capacity for collaborative learning, knowledge sharing, knowledge construction, and social presence. Ekici (2017) investigated 58 pre-service science teachers. The respondents were requested to share the skills and knowledge that they have learned in the physical classroom via Edmodo. They were also given the opportunity to discuss their lesson plans or ideas that they have towards certain pedagogical tools on the Edmodo platform. As a result, the learners have indicated that although the accessibility to Edmodo is sometimes disrupted by poor internet network connections, Edmodo is regarded as an interactive educational platform because it allows learners to share ideas, build their lesson plan, and practice their skills flexibly (Ekici, 2017). According to Alzain (2019), the major challenges faced by most of the learners are the insufficient time to participate in the teaching and learning activities through Edmodo as they were occupied with assignment deadlines and tasks assigned in other courses. Nevertheless, Alzain (2019) highlights that Edmodo is still preferred as an effective medium for interaction and collaboration by the students.

However, Wenger et al. (2002) point out that it is not easy to cultivate an effective community of practice as it requires 'careful seeding'. In the education environment, this means that educators have an overwhelming task in facilitating the learners' learning process by prompting them to participate actively in the community. This is in tandem with the views of Fisher et al. (2014) who have mentioned the reasons as to why educators need a fair amount of time to develop appropriate resources that are aligned with the communities' needs and to encourage the learners to be a part of the virtual community. Yet, another important setback worth considering is the prevailing habit of downloading content materials instead of contributing them to the community (Ali, 2015). Thus, some scholars state that once the VCoP is successfully developed, it would not only enhance the community's professional skills but also enrich their social relationship, boost confidence, and increase motivation skills (Ekici, 2017; Wenger et al., 2002), which eventually encourage the participants to author and share content to the community (Fisher et al., 2014).

\section{Past Studies on the Use of Edmodo in English for Specific Purposes Courses}

Many ESP scholars have stated that an ESP course is not merely about passing exams but more about developing learners' capabilities in performing their language skills and subject matter in authentic situations (Dudley-Evans \& St. John, 1998; Javid, 2015; Jendrych, 2013). Therefore, Smoak (2003) explains, that appropriate medium of teaching should be employed to meet learners' needs and to achieve the course learning outcome. Robinson (1991) and Silva et al. (2013) even have highlighted that elements such as independent, lifelong, and cooperative learning are emphasised in the ESP course to produce professional employees.

Andrienko (2017) who investigated the attitude of 60 Technical English learners towards the effectiveness of Edmodo as a collaborative platform found that most of the respondents enhanced their communicative competencies through regular communication. Andrienko (2017) reiterates 
that the features in the Edmodo boosted the teamwork activities among the learners. In a similar study, Dogoriti and Pange (2014) explain that most ESP learners enjoyed engaging themselves in the Edmodo for learning activities as they could post their comments easily through the platform. Ngo and Ngadiman (2019) who studied the use of Edmodo among ESP learners from the engineering program have found that the more often learners engaged themselves in the Edmodo activities like doing quizzes, giving comments, and reading lecture notes, the better they have scored academically. Despite the benefits that Edmodo could offer to its users, some learners claim that the use of Edmodo in the teaching and learning process is time-consuming and sometimes it leads to plagiarism as some learners copy the work of other learners that was posted on the platform (Enriquez, 2014).

Most of the studies on the use of Edmodo in the ESP courses mainly focus on the development of learners' language skills. For example, Warawudhi (2017) measured the attitude of 54 Business English learners towards the use of Edmodo in a reading class. She found that almost every learner showed satisfaction towards the effectiveness of Edmodo in the reading class. However, lack of motivation hindered some of them from being active in the platform (Warawudhi, 2017). Other scholars investigated the use of Edmodo in writing skills (Chong, 2018; Djamal, 2018; Nguyen \& Nguyen, 2019; Purnawarman et al., 2016) and speaking skills (Sofia \& Phil, 2018), and they have discovered that Edmodo helped the learners in developing their language skills. In fact, there have not been many studies on the use of Edmodo in Business English. Till to date, the investigation of using Edmodo in Business English classes has only been conducted by Djamal (2018) and Warawudhi (2017) in which both studies concentrate on the effectiveness of Edmodo in reading and writing skills respectively.

A study that highlights the potential of Edmodo as a VCoP platform among ESP learners is yet to be conducted. There is still a dearth of a comprehensive study on the use of Edmodo for knowledge contribution, social presence, engagement, interaction, and collaboration in the teaching and learning of ESP courses (Andrienko, 2017; Ngo \& Ngadiman, 2019). In short, there is a need for further investigation to determine ESP learners' experiences of using Edmodo as a platform for a VCoP that encompasses knowledge sharing, building expertise, ongoing interaction, collaboration, and creating social identity (Wenger et al., 2002).

\section{METHOD}

\section{Participants}

This study was conducted over 10 weeks in Semester 1: 2019/2020 from one of the public universities in Malaysia. The participants in this study comprised 30 undergraduates learning Business English course with 11 male and 19 female students. The participants were selected through the convenience sampling method. Table 1 shows the descriptive statistics of the participants' proficiency levels. The learners' proficiency level was determined based on the grades that the learners obtained from Malaysian University English Test (MUET).

Table 1. Descriptive statistics of participants' proficiency

\begin{tabular}{crr}
\hline Proficiency Level & Frequency & Percent \\
\hline intermediate & 14 & 46.7 \\
upper- & 16 & 53.3 \\
intermediate & 30 & 100.0 \\
Total & \\
\hline
\end{tabular}




\section{Research procedure and design}

In this study, mixed-method research was employed to answer the research questions. Thus, the sequential explanatory design opted in which the researcher collected and analysed data in the quantitative phase first before the qualitative phase has proceeded.

This study was aimed to investigate Business English learners' experiences of using Edmodo as a platform for a VCoP. Therefore, Edmodo was used for the following activities:

I. Virtual discussion on issues related to Business English such as presentation skills, negotiation skills, writing skills, and job interview skills.

II. Develop and share knowledge with one another. For example, learners were requested to post their oral presentation video in Edmodo as an attempt to encourage them to contribute their knowledge and receive feedback or comments from other learners and educators.

III. Ongoing discussion in a small group with five to six people in a group. Throughout the discussion, they would share their knowledge, website links, and personal experiences based on the Business English reading text.

IV. Collaboration in writing activities. Learners would collaborate with their team members in the small group in writing a short report.

V. Participation in online quizzes and games through Edmodo.

VI. The educator would monitor the interaction among the learners and give comments based on the learners' feedback. This was to ensure that the VCoP can be employed dynamically.

On the $10^{\text {th }}$ week of the course, a survey was conducted by distributing a set of questionnaires that consisted of respondents' demographic profiles and 21 five-point Likert scale statements. The 21 items in the questionnaire were developed based on the criteria suggested by Wenger et al. (2002) and Fisher et al. (2014) on the formation of a successful VCoP. These include the abilities to use Edmodo for knowledge sharing and construction, interaction and collaboration, social identity, and ease of use. The questionnaire was validated by a panel of experts, comprising two ESP practitioners and two content specialists. Next, ten participants were selected for a focus group discussion to get better results on their views towards the use of Edmodo as a platform for a VCoP. The participants were selected using stratified random sampling based on their English proficiency level. As such, five intermediate learners and five upper-intermediate learners took part in the focus group discussion.

\section{Data analysis}

In order to answer research question 1, data were collected through a questionnaire survey. Data were analysed through the mean score and one-way ANOVA test. The reliability of the questionnaire items was 0.82. According to Creswell (2014), Cronbach's alpha value of a questionnaire that exceeds 0.7 is considered reliable and that the questionnaire can be used for research. The items from the questionnaire were computed to 'knowledge sharing and construction', 'interaction and collaboration', 'social identity', and 'ease of use' through the SPSS version 20 .

In order to triangulate the quantitative data and to answer the second research question, a focus group discussion was conducted among ten Business English learners who had completed the questionnaire. The data obtained from the focus group discussion was analysed using thematic 
analysis. Consequently, two themes were divided namely, 'learners' perceptions towards the use of Edmodo' and 'challenges of using Edmodo'. The former was analysed under four sub-themes: 'knowledge sharing and construction', 'interaction and collaboration' 'social identity', and 'the ease of use', which were developed based on the literature (deductive mode). The latter focused on an inductive mode that allows learners to generate new ideas and issues pertaining to the challenges of using Edmodo as a platform for a VCoP.

\section{RESULTS AND DISCUSSION}

The findings of the study were presented based on the research questions. Quantitative data was used to answer the first research question while qualitative data was used to answer the first and second research questions.

\section{Research question 1}

Table 2 shows learners' experiences in using Edmodo in terms of knowledge sharing and construction, interaction and collaboration, social identity, and ease of use.

Table 2. The mean score of Business English learners' perception of their experiences in using Edmodo as a platform for a virtual community of practice

\begin{tabular}{|l|l|}
\hline ESP Learners' Perception towards Edmodo & Mean Score \\
\hline Knowledge sharing and construction & 3.95 \\
\hline Interaction and collaboration & 4.06 \\
\hline Social identity & 3.87 \\
\hline Ease of use & 3.87 \\
\hline
\end{tabular}

Table 2 shows that most of the respondents perceived Edmodo as an effective platform for a VCoP. They utilised Edmodo mainly for interaction and collaboration (mean score $=4.06$ ) and also for knowledge sharing and construction (mean score $=3.95$ ). The findings of this study are in line with the past studies' result that Edmodo could create an effective platform for virtual discussion and collaboration (Ali, 2015; Zainal Abidin et al., 2018) and for knowledge sharing (Balasubramaniam et al., 2014). This indicates that the learners have the opportunity to share knowledge, communicate ideas, and collaborate with others through Edmodo, which complies with the characteristics of VCoP. According to Fisher et al. (2014), an effective VCoP is built when participants in the community able to acquire and share knowledge without any obstacles.

The data also show that the potential of Edmodo in creating social identity and ease of use have the least mean scores, 3.87. This indicates that frequent communication is needed to build one's self-esteem, which eventually will increase the participant's sense of belonging to the community (Wenger et al., 2002). The researchers concur with Fisher et al. (2014), that once learners started to interact more and engage themselves in the virtual discussion, they eventually have built a sense of belonging to the community. Although the literature suggests that Edmodo is user-friendly (Thongmak, 2013), the quantitative results show that many learners still struggle in operating Edmodo for learning purposes.

As additional information, it was found that the use of Edmodo for interaction and collaboration is statistically significant in terms of learners' proficiency level with p-value $=.016$. Table 3 shows that upper-intermediate learners participate actively in the interaction and collaboration activities $($ mean $=4.21)$ compared to the intermediate learners $($ mean=3.88). This is probably because the 
better command of language among upper-intermediate learners encouraged them to post their comments or feedback more than intermediate learners.

Table 3. One Way Anova Test between the use of Edmodo for interaction and collaboration based on learners' proficiency

\begin{tabular}{|l|l|r|r|c|}
\hline & Proficiency & $\mathrm{N}$ & Mean & Sig, \\
\hline Interaction \& & intermediate & 14 & 3.88 & \multirow{2}{*}{ Collaboration } \\
\cline { 2 - 4 } & $\begin{array}{l}\text { upper- } \\
\text { intermediate }\end{array}$ & 16 & 4.21 & .016 \\
\hline
\end{tabular}

The researchers also found that the major purpose for the ESP learners to use Edmodo is to gain knowledge. Table 4 shows the mean score of the selected items from the questionnaire. Based on Table 4, most of the ESP learners acquire knowledge through interaction with a teacher (mean score $=4.30$ ) and classmates (mean score $=4.17$ ). This result is in tandem with Ali's (2015) findings that most of the learners in English language classrooms mainly use Edmodo to learn or acquire knowledge on the English subject. However, it is crucial to take note that the respondents from the present study used Edmodo not only to gain knowledge but also to develop new ideas (mean score $=4.10$ ). This is mainly because, according to Dudley-Evan and St. John (1998), ESP learners are usually competent with the content matter and therefore it is important for the ESP practitioners to acknowledge their expertise in their respective fields. As such, competent learners tend to utilise the platform to construct new information to be shared with others in the community. Table 5 portrays that these learners were willing to develop new ideas and experiences and share them on the platform. This shows that learners were not only comfortable with obtaining knowledge but also had the responsibility of contributing information to the community. It is also important to be aware that Table 4 shows that the range between the highest and lowest mean score is very small. It can be said that the application of Edmodo in Business English also improves learners' communication skills (mean score $=3.70$ ) especially in writing skills (refer to Table 5).

Table 4: The mean scores of selected questionnaire items

\begin{tabular}{|l|c|c|}
\hline Questionnaire items & Mean & $\begin{array}{c}\text { Std. } \\
\text { Deviation }\end{array}$ \\
\hline $\begin{array}{l}\text { I acquire knowledge when I interact with } \\
\text { teacher through Edmodo. }\end{array}$ & 4.300 & .534 \\
\hline $\begin{array}{l}\text { My interaction with other classmates } \\
\text { through Edmodo is beneficial. }\end{array}$ & 4.166 & .698 \\
\hline $\begin{array}{l}\text { I am able to create new ideas through } \\
\text { Edmodo. }\end{array}$ & 4.100 & .758 \\
\hline $\begin{array}{l}\text { I enjoy the sense of belonging while } \\
\text { interacting through Edmodo. }\end{array}$ & 3.866 & .628 \\
\hline $\begin{array}{l}\text { Edmodo enhances my communication } \\
\text { skills. }\end{array}$ & 3.700 & .836 \\
\hline $\begin{array}{l}\text { I am able to access course materials } \\
\text { easily through Edmodo. }\end{array}$ & 3.933 & .784 \\
\hline
\end{tabular}

A focus group discussion was conducted to study further on Business English learners' perception of their experiences in using Edmodo as a platform for a VCoP. The following examples show some of the questions that were asked in the focus group discussion:

I. Do you think you could share information easily through Edmodo? 
II. In your opinion, can you collaborate with your other classmates through Edmodo?

III. Do you feel comfortable being in the Edmodo group?

Table 5 shows the responses of Business English learners on their experiences of using Edmodo as a platform for VCoP. The responses are categorised based on the frequency of similar answers. In order to maintain the anonymity of the participants, the researcher identified them by using codes (S1 to $\mathrm{S} 10)$.

Table 5. Common Responses from the Focus Group Discussion

\begin{tabular}{|c|c|}
\hline Themes & Responses \\
\hline Knowledge sharing and construction & $\begin{array}{l}\text { - Easily can share information and links through the } \\
\text { 'post' feature (S1 to S10) } \\
\text { - Enjoy reading friends' post (S1, S2, S5, S6, S10) } \\
\text { Teachers' posts and comments were beneficial } \\
\text { (S1 to S10). } \\
\text { Some students have the tendency to copy the } \\
\text { messages and post them in Edmodo (S2, S3, S6, } \\
\text { S8). } \\
\text { Ability to share new ideas and experiences (S1, } \\
\text { S4, S8, S9). } \\
\text { Continuous improvement in writing skills and } \\
\text { vocabulary (S1 to S10). }\end{array}$ \\
\hline Interaction and collaboration & $\begin{array}{l}\text { Easy to interact with others through the small- } \\
\text { group feature }(\mathrm{S} 1, \mathrm{~S} 2, \mathrm{~S} 3, \mathrm{~S} 5, \mathrm{~S} 7, \mathrm{~S} 8, \mathrm{~S} 9) \text {. } \\
\text { Able to send personal messages to the teacher (S3, } \\
\mathrm{S} 5, \mathrm{~S} 6, \mathrm{~S} 7, \mathrm{~S} 9, \mathrm{~S} 10) \text {. } \\
\text { Knowledge was acquired despite facing } \\
\text { challenges of working with team members (S3, } \\
\mathrm{S} 8, \mathrm{~S} 9, \mathrm{~S} 10) \text {. } \\
\text { Peer influence allows active participation from } \\
\text { other members (S1, S2, S5, S7). } \\
\text { Inability to get full cooperation from all the team } \\
\text { members for group work }(\mathrm{S} 3, \mathrm{~S} 8, \mathrm{~S} 9, \mathrm{~S} 10) \text {. }\end{array}$ \\
\hline Social identity & $\begin{array}{l}\text { Low language proficiency hinders them from } \\
\text { participating in the online discussion (S4, S5, S7). } \\
\text { Ability to build a good relationship with team } \\
\text { members (S1, S2, S6, S8). } \\
\text { Feeling of being appreciated when comments } \\
\text { were acknowledged (S3, S4, S6). } \\
\text { Received good assistance from team members to } \\
\text { troubleshoot difficulties that arise with Edmodo } \\
\text { (S7, S9). } \\
\text { Good support from the teacher to post comments } \\
\text { (S1, S5, S7, S8, S9, S10). }\end{array}$ \\
\hline Ease of use & $\begin{array}{ll}\text { Edmodo is user-friendly (S1, S3, S4, S5, S9). } \\
\text { - Easy to learn (S1, S2, S3, S5, S6, S8, S9, S10) } \\
\text { - Flexibility to interact with teachers and other }\end{array}$ \\
\hline
\end{tabular}


classmates (S1, S2, S5, S8, S9, S10).

- Poor internet connection slows down the loading process (S7).

- Proper training on the use of Edmodo should be given to the learners (S5, S7, S8, S9, S10).

The responses from the ESP learners show that most of them are in favour of using Edmodo for interaction purposes as they find the platform gives them the opportunity to communicate with ease through instant messages and small-group features. This explains that small-group feature plays an important role in attracting learners' participation because learners feel comfortable in communicating with fewer people in the group (Akcaoglu \& Lee, 2016). Besides, peer pressure has become another reason for the learners to participate in the Edmodo. It is also important to note that the responses from the group discussion show that some learners could build a social identity as they feel their presence is being recognised in the Edmodo group especially when they receive feedback or 'likes' from other learners. However, some of the learners hesitate to interact virtually due to a lack of confidence in their proficiency. According to Fisher et al. (2014), a social identity is developed gradually as it will take time for the learners to adapt themselves to the newly created group. Therefore Wenger et al. (2002) point out that frequent interaction in the group is necessary to build a social relationship with the participants in the community and also to increase one's expertise. In terms of ease of use, although the ESP learners agreed that Edmodo provides flexible interaction, poor internet connection has always been a concern. In fact, many researchers also agree that the internet problem disrupts the online teaching and learning process (Andrienko, 2017; Warawudhi, 2017). The data from Table 5 shows that learners perceive Edmodo as a platform that can be easily learned. Hence, it eases the interaction with one another.

Overall, Edmodo has the potential to create an effective platform for a VCoP where the ESP learners have the chance to contribute their knowledge, build confidence, be active learners, and take responsibility for their own learning.

\section{Research question 2}

The literature and the results of this study showed that most of the learners preferred using Edmodo in the ESP classes. Many claimed the effectiveness of Edmodo in improving learners' academic performance (Ngo \& Ngadiman, 2019) and language skills (Djamal, 2018, Nguyen \& Nguyen, 2019; Warawudhi, 2017). Nevertheless, it is important to highlight the potential limitations of using Edmodo to gain a better understanding of the implementation of Edmodo as a platform for a VCoP among ESP learners.

According to Wenger et al. (2002), a successful community of practice is achieved when the participants in the community can share their ideas, interests, and knowledge with others. Literature and the findings of the current study revealed the effectiveness of Edmodo in sharing knowledge (Thongmak, 2013; Zainal Abidin et al., 2018). In this study, when the participants were asked about the challenges that they encountered while sharing knowledge through Edmodo, many participants indicated that they can share their ideas effortlessly through Edmodo. However, some participants especially the intermediate learners, claimed that unfamiliarity in using Edmodo at the initial stage has hindered them from sharing knowledge. This is because Edmodo was exposed for the first time to the participants in the ESP course. An intermediate participant stated: 
"I find Edmodo difficult to use at the beginning. I had to ask my friends where to attach file. But now, I can use easily" (S4).

Another intermediate participant stated:

"Using Edmodo for sharing ideas and knowledge is not a problem at all. My main issue is when need to upload video. Sometimes, when the file is too large, I find it difficult to upload it. Anyway, after that, I learned that if I can't upload the file, I can upload in youtube or google drive, and share the link in Edmodo. In this way, I feel easy to share" (S5).

The researchers agree with past scholars, that Edmodo is user-friendly and it is convenient to be used in education (Ali, 2015; Enriquez, 2014; Warawudhi, 2017). However, sufficient training on the use of Edmodo should be given to learners before embedding it in the teaching and learning process. This is because some new users struggle to use Edmodo at the initial stage. An intermediate participant indicated:

"It's better if someone could give us some sort of lesson on how to use Edmodo before we start using it in our course. Anyway, it's easy to learn. My friend taught me how to use it" (S7).

The results from the literature and the quantitative study showed the effectiveness of Edmodo for collaboration and interaction. Nevertheless, when the participants were asked about the challenges that they encountered in collaborating with other learners, some learners indicated that the lack of cooperation from other learners sometimes procrastinates their group work. An upper-intermediate learner stated:

"The small-group in Edmodo actually helps us to communicate well with other members. But, sometimes for group activities, some members don't share their opinions at all, especially for the writing activities. I had to work with the same three people in the group. In fact, there are five people in my group" (S3).

Collaborative learning does not take place based on the features in Edmodo alone (e.g. smallgroup) but also based on the types of learning activities and motivations that were given to the learners. Literature suggests that motivation is an effective tool to bring learners together as one community. The researchers agree with Fisher et al. (2014), that educators play an essential role in encouraging learners to get engaged and collaborate in the virtual community.

The participants were also asked about their challenges in building social identity in the Edmodo group. Some of the participants, especially intermediate learners indicated that low proficiency in the English language hinders them from interacting confidently with their team members. One intermediate learner stated:

"All my team members have better English than me. When we do discussion, they can really come out with good ideas with good words. Yes, I can learn from them but..., I feel difficult to share my ideas. I feel shy. So, I don't really enjoy to be in that group. It is better if we can choose our own team members" (S7)

Finally, other common challenges that the participants faced in using Edmodo were internet connection problems and plagiarism. The results are in tandem with past studies that showed 
similar limitations in using Edmodo (Enriquez, 2014; Mokhtar, 2018). Table 5 also shows some of the learners' challenges in using Edmodo as a platform for a VCoP.

In short, it has been found out that many intermediate learners have highlighted insufficient knowledge on the use of Edmodo, and difficulties to collaborate with learners with a higher level of English proficiency have become the major challenges in using Edmodo as a platform for a VCoP. Besides, upper-intermediate learners also shared a similar concern, which is the difficulty of getting cooperation from the team members.

\section{CONCLUSION AND RECOMMENDATION}

In conclusion, Edmodo is an effective platform in building VCoP for ESP learners. The learners were able to develop their knowledge on content matter and skills through frequent interaction and collaboration with other learners from the Edmodo group. The researchers concur with Akcaoglu and Lee (2016) that small-group is a good tool to enhance learners' discussion, writing skills, and their confidence level because learners feel comfortable in sharing knowledge, opinion, ideas, and personal experience in a small group that contains fewer people.

However, it is important to highlight that some learners could not feel like being a part of the community and this probably occurs due to their low proficiency in the English language. Nevertheless, Fisher et al. (2014) point out that ongoing discussion would eventually rope these learners into the community where they would gradually learn even to defend their opinions. Thus, with frequent engagement in Edmodo, it is believed that ESP learners would be able to apply knowledge and skills that they have gained in authentic situations. The learners would also be able to improve their proficiency level through regular communication.

It is also important to address possible limitations that could occur in using Edmodo so that appropriate actions could be taken to create an enjoyable and meaningful learning experience. Issues such as plagiarism, incompetency in using Edmodo, the difficulty of collaborating, and different levels of proficiency should be tackled while developing an efficient VCoP in the ESP course. Therefore, both ESP practitioners and active members in Edmodo should encourage and motivate learners who participate less or peripheral learners by giving them positive remarks on their contribution. Besides, sufficient training and technical assistance should be provided for those who are in need. In addition, members in the small-group Edmodo should comprise learners with mixed proficiency levels so that learners will feel comfortable in communicating with the team members. The researchers agree with past researchers who have indicated that learners will enjoy the sense of belonging in a group when they feel comfortable sharing their thoughts (Akcaoglu \& Lee, 2016; Fisher et al., 2014).

It is suggested that educators should employ the VCoP approach in their teaching as it promotes lifelong and autonomous learning. Besides, they also play a crucial role to motivate the learners especially the shy and weak ones to take up the challenge in sharing knowledge and contributing new ideas. ESP course developers should also consider embedding the VCoP approach in the curriculum to achieve the learning outcomes of the course. Edmodo is an educational tool where it allows interaction from a various group of people (e.g. teachers, learners, parents) to build knowledge together in a safe environment. Thus, ESP educators should consider using Edmodo in their teaching and learning process by giving room for the ESP learners to share their knowledge. 
Frequent interaction and collaboration will enable learners to equip themselves with specific terms, subject matter, language use, and language skills related to their ESP course.

The present study is limited to only one group of ESP learners and therefore, future studies should look into other ESP courses with larger sample size. Besides, further investigation is needed to determine the acceptance of Edmodo as a VCoP platform for ESP learners.

\section{REFERENCES}

Akcaoglu, M., \& Lee, E. (2016). Increasing social presence in online learning through small group discussions. The International Review of Research in Open and Distributed Learning, 17(3), https://doi.org/10.19173/irrodl.v17i3.2293

Ali, Z. (2015). A case study of tertiary student's' experiences using Edmodo in language learning. International Journal of Language Education and Applied Linguistics (IJLEAL), 2(1), 3948. https://doi.org/10.15282/ijleal.v2.462

Alzain, H. A. (2019). The role of social networks in supporting collaborative e-learning based on connectivism theory among students of PNU. Turkish Online Journal of Distance Education, 20(2), 46-63. https://files.eric.ed.gov/fulltext/EJ1213120.pdf

Andrienko, A. (2017). The role of virtual educational environment in English for specific learning purposes. Advances in Computer Science Research, 72, 209-215. https://doi.org/10.2991/itsmssm-17.2017.45

Balasubramaniam, K., Jaykumar, V., \& Leena N. F. (2014). A study on student preference towards the use of Edmodo as a learning platform to create responsible learning environment. Social and Behavioral Sciences, 144, 416-422. https://doi.org/10.1016/j.sbspro.2014.07.311

Chong, Jui Jong (2018). The effects of using Edmodo small groups on university ESL students' writing achievement and writing apprehension. [Unpublished master's thesis]. Universiti Sains Malaysia.

Creswell, J. W. (2014). Research design: Qualitative, quantitative and mixed method approaches. (4th ed.). SAGE Publications.

Djamal, M. (2018). Implementation of blended learning model based on Edmodo application to improve English for specific purposes (ESP) learner's interest. Journal Bahasa Lingua Scientia, 10(2), 313-328. https://doi.org/10.21274/ls.2018.10.2.313-328

Dogoriti, E., \& Pange. J. (2014). Instruction design for a "social" classroom: Edmodo and Twitter the foreign language classroom. In Proceedings of the International Conference on Information Communication Technologies in Education, pp. 154-165.

Dudley-Evans, T., \& St. John, M. J. (1998). Developments in English for Specific Purposes: A multi-disciplinary approach. Cambridge University Press.

Ekici, D. I. (2017). The use of Edmodo in creating an online learning community of practice for learning to teach science. Malaysian Online Journal of Educational Sciences, 5(2), 91106. https://files.eric.ed.gov/fulltext/EJ1142512.pdf

Enriquez, M. A. S. (2014). Students' perceptions on the effectiveness of the use of Edmodo as a supplementary tool for learning. In DLSU Research Congress, pp. 1-6.

Fisher, A., Exley, K., \& Ciobanu, D. (2014). Using technology to support learning and teaching. Routledge. 
Javid, C. Z. (2015) English for specific purposes: Role of learners, teachers and teaching methodologies. European Scientific Journal, 11, 17-34. http://eujournal.org/index.php/esj/article/view/5950/5736

Jendrych, E. (2013). Developments in ESP teaching. Studies in Logic, Grammar and Rhetoric, 34(47), 43-58. https://doi.org/10.2478/slgr-2013-0022

Mokhtar, F. (2018). Breaking barriers through Edmodo: A qualitative approach on the perceptions of University of Malaya undergraduates. Online Learning, 22(1), 61-80. https://doi.org/10.24059/olj.v22i1.1026

Ngo, J., \& Ngadiman, A. (2019). The impacts of Edmodo on students' performance in ESP classrooms. International Seminar on Language, Education, and Culture, 3(10), 369-378. https://doi.org/10.18502/kss.v3i10.3918

Nguyen, H. B., \& Nguyen, B. T. P. (2019). Edmodo use in ESP writing: Students' perceptions. European Journal of English Language Teaching, 4(4), 130-140. https://doi.org/10.5281/zenodo.3240463

Purnawarman, P., Susilawati, S., \& Sundayana, W. (2016). The use of Edmodo in teaching writing in a blended learning setting. Indonesian Journal of Applied Linguistics, 5(2), 242-252. https://doi.org/10.17509/ijal.v5i2.1348

Penfold, P. (2010). Virtual communities of practice: Collaborative learning and knowledge management. Third International Conference on Knowledge Discovery and Data Mining. pp. 482-485. https://doi.org/10.1109/WKDD.2010.70

Robinson, P. (1991). ESP today: A practitioner's Guide. Prentice Hall.

Silva, A., Lourtie, P., \& Aires, L. (2013). Employability in online higher education: A case study. International Review of Research in Open and Distance Learning, 14(1), 106-125. https://doi.org/10.19173/irrodl.v14i1.1262

Smoak, R. (2003). What is English for specific purposes? English Teaching Forum Online, 41(2), 22-27. http://americanenglish.state.gov/ files/ae/resource_files/03-41-2-g.pdf

Sofia, H., \& Phil, M. (2018). Video recordings of oral presentation skills and Edmodo app to enhance presentation skills of students. Challenges and Opportunities for Teaching and Research in English Language and Literature, 18(6), 110-119. http://www.languageinindia.com/june2018/vitseminarenglish/sofiaoralpresentationfinal.pd $\mathrm{f}$

Soto, M. A., \& Waigandt, D (2017). Authenticity in ESP course: Building communities of practice. In D.L. Benegas, M. Lopez-Barrios \& D. Waigandt (Eds.) Authenticity in ELT: Selected Papers from the $42^{\text {nd }}$ FAAPI Conference, pp. 109-118. Posadas.

Thongmak, M. (2013). Social network system in classroom: Antecedents of Edmodo adoption. Journal of e-Learning and Higher Education, 2013, 1-15. https://doi.org/ $10.5171 / 2013.657749$

Tyagi, S. (2012). Adoption of Web 2.0 technology in higher education: A case study of Universities in National Capital Region, India. International Journal of Education and Development using Information and Communication Technology (IJEDICT), 8(2), 28-43. https://files.eric.ed.gov/fulltext/EJ1084132.pdf

Warawudhi, R. (2017). The evaluation of Edmodo in business reading class. International Journal of Information and Education Technology, 7(2), 153-158. https://doi.org/10.18178/ijiet.2017.7.2.858

Wenger, E., McDermott, R. A., \& Snyder, W. (2002). Cultivating communitie s of practice: A guide to managing knowledge. Harvard Business Press. 
Yunkul, E., \& Çankaya, S. (2017). Students' attitudes towards Edmodo, a social learning network: A scale development study. Turkish Online Journal of Distance Education, 18(2), 16-29. https:// doi:10.17718/tojde.306554

Zainal Abidin, N. A., Abu Bakar, A. H., \& Ali, Z. (2018). Web 2. 0: A collaborative learning approach using Edmodo in group discussion. Journal of Humanities, Language, Culture and Business (HLCB), 2(10), 26-36. http://www.icohlcb.com/images/Articles/vol_2_No.10/Paper-148-.pdf 